\title{
A proposal for the reclassification of Bdellovibrio stolpii and Bdellovibrio starrii into a new genus, Bacteriovorax gen. nov. as Bacteriovorax stolpii comb. nov. and Bacteriovorax starrii comb. nov., respectively
}

\author{
Marcie L. Baer, ${ }^{1} \dagger$ Jacques Ravel, ${ }^{2} \ddagger$ Jongsik Chun, ${ }^{2} \S$ Russell T. Hill ${ }^{2}$ \\ and Henry N. Williams ${ }^{1}$
} Author for correspondence: Marcie L. Baer. Tel: +1 205348 1820. Fax: + 12053481786.
e-mail: mbaer@biology.as.ua.edu

1 Department of Oral and
Craniofacial Biological
Sciences, University of
Maryland at Baltimore,
666 W. Baltimore Street,
Baltimore, MD 21201, USA
2 Center of Marine
Biotechnology, University
of Maryland
Biotechnology Institute,
701 East Pratt Street,
Baltimore, MD 21201, USA

\begin{abstract}
Bdellovibrios are unique bacteria with the ability to prey upon a wide variety of susceptible Gram-negative bacteria. Micro-organisms exhibiting this trait have been included in the genus Bdellovibrio despite their isolation from diverse habitats and relatively unstudied taxonomic relatedness. In this study, $16 S$ rDNA sequences were compared from known terrestrial Bdellovibrio species, Bdellovibrio bacteriovorus ${ }^{100^{\top}}$, Bdellovibrio stolpii Uki2 ${ }^{\top}$ and Bdellovibrio starrii $A 3.12^{\top}$ in order to study their phylogenetic relationship. The two sequences from $B$. stolpii Uki2 ${ }^{\top}$ and $B$. starrii $A 3.12^{\top}$ were $90.0 \%$ similar to each other but exhibited only $81 \cdot 7 \%$ and $81 \cdot 2 \%$ similarity, respectively to $B$. bacteriovorus $100^{\top}$. Phylogenetic analysis indicated that $B$. bacteriovorus $100^{\top}$ clustered in a separate clade from B. starrii A3.12 ${ }^{\top}$ and B. stolpii Uki2 ${ }^{\top}$, demonstrating only a distant relationship between $B$. bacteriovorus $100^{\top}$ and the other two recognized type species. DNA-DNA hybridization experiments also demonstrated $<4 \%$ hybridization between these three species. On the basis of the results obtained from the phylogenetic analysis and DNA-DNA hybridization studies, it is proposed that B. stolpii Uki2 ${ }^{\top}$ and B. starrii A3.12 ${ }^{\top}$ should be transferred to a new genus, Bacteriovorax gen. nov. as Bacteriovorax stolpii comb. nov. and Bacteriovorax starrii comb. nov., respectively. It is also proposed that the type species for the new genus Bacteriovorax should be Bacteriovorax stolpii comb. nov.
\end{abstract}

Keywords: Bdellovibrio, taxonomy, $16 \mathrm{~S}$ rDNA

\section{INTRODUCTION}

Bdellovibrios are unique, obligately predatory bacteria that prey upon a wide variety of susceptible Gram-

\footnotetext{
†Present address: The University of Alabama, Department of Biological Sciences, Box 870344, Tuscaloosa, AL 35487, USA.

$\ddagger$ Present address: The Johns Hopkins University, Chemistry Department, 235 Remsen Hall/3400 N. Charles St, Baltimore, MD 21218, USA.

$\S$ Present address: Korean Collection for Type Cultures, Korea Research Institute of Bioscience and Biotechnology, Yusong, Taejon 305-600, Republic of Korea.

Abbreviation: PI, prey-independent.

The EMBL accession numbers for the 16S rDNA sequences of Bdellovibrio bacteriovorus $100^{\top}$ and Bacteriovorax starrii are AF084850 and AF084852, respectively.
}

negative micro-organisms. Wild-type bdellovibrios must be cultivated in mixed culture with their prey. This poses a real challenge to conventional characterization which relies on growth of the organisms in pure culture for taxonomic analysis. The isolation of prey-independent (PI) mutant strains of Bdellovibrio which can be grown in pure culture circumvents the difficulties of studying the organisms in dual culture. Ribotype and 16S rDNA sequence similarity studies in our laboratory (Baer et al., 1998) as well as phage susceptibility studies (Varon \& Levisohn, 1972) comparing wild-type strains to their equivalent mutant strains have revealed no differences between the forms.

In the past, predatory bacteria exhibiting the typical intraperiplasmic cell cycle described by Starr \& Baigent 
(1966) were included in the genus Bdellovibrio without consideration of their genetic relationship and despite large differences in $\mathrm{G}+\mathrm{C}$ ratios $(6-10 \mathrm{~mol} \%$ and in some cases, as high as $15 \mathrm{~mol} \%$ ) (Burnham \& Conti, 1984; Seidler et al., 1972).

Results from early molecular studies of different Bdellovibrio strains, including Bdellovibrio bacteriovorus $100^{\mathrm{T}}$, Bdellovibrio stolpii $\mathrm{Uki}^{\mathrm{T}}$ and Bdellovibrio starrii $\mathrm{A} 3.12^{\mathrm{T}}$, suggested that bdellovibrios are a phylogenetically heterogeneous group of microorganisms (Donze et al., 1991; Hespell et al., 1984; Oyaizu \& Woese, 1985; Stackebrandt, 1988; Woese, 1987). Previous studies revealed variations in $G+C$ content (mol\%) and low DNA-DNA hybridization between strains with different $\mathrm{G}+\mathrm{C}$ ratios (Seidler et al., 1972). Other studies of Bdellovibrio species have demonstrated low similarity values between partial 16S rRNA sequences (Donze et al., 1991) as well as substantially different restriction enzyme profiles (Baer et al., 1998; Scognamiglio \& Tudor, 1996). High levels of diversity among Bdellovibrio species has also been demonstrated using physiological and cultural characteristics such as fatty acid composition (Guether et al., 1993), antibiotic resistance patterns (Guether \& Williams, 1993) and enzymic activities (H. N. Williams, unpublished data). An analysis of serological properties (Schelling et al., 1977), phage typing and physiological properties of the organisms has revealed that all three recognized species (B. bacteriovorus $100^{\mathrm{T}}$, B. stolpii $\mathrm{Uki}^{\mathrm{T}}$ and B. starrii $\mathrm{A} 3.12^{\mathrm{T}}$ ) form distinct groups (Althauser et al., 1972; Hashimoto et al., 1970; Varon \& Levisohn, 1972).

The collective results from these studies demonstrate that the use of predatory behaviour as the sole defining property for placing organisms within the Bdellovibrio genus has resulted in a collection of molecularly diverse organisms and suggests a taxonomic separation of $B$. stolpii $\mathrm{Uki}^{\mathrm{T}}$ and $B$. starrii $\mathrm{A} 3.12^{\mathrm{T}}$ from the Bdellovibrio bacteriovorus group. This suggestion is proposed by the authors of Bergey's Manual of Systematic Bacteriology (Burnham \& Conti, 1984). The authors stated that the diversity of the members assigned to the genus Bdellovibrio 'places considerable stress upon the concept of a single genus ...'. However, they chose not to propose changes at that time perhaps due to gaps in the information needed to substantiate the argument for change. New molecular methods are now available and in wide use to obtain the needed information to fill the gaps in the nucleic acid composition of these micro-organisms.

The comparison of rDNA sequences has become a powerful evolutionary tool for determining phylogenetic relationships (Weisburg et al., 1991). Woese (1987) proposed that rDNA sequences provide the most useful and stable 'molecular clock' for phylogenetic analyses. These sequences are found in all organisms and can be sequenced directly through application of PCR (Saiki et al., 1988).
In the present investigation, complete $16 \mathrm{~S}$ rDNA sequences from three Bdellovibrio sp., B. bacteriovorus $100^{\mathrm{T}}$, B. stolpii $\mathrm{Uki} 2^{\mathrm{T}}$ and B. starrii $\mathrm{A} 3.12^{\mathrm{T}}$, were compared in order to clarify their taxonomic relationship. DNA-DNA hybridization studies were used as a complementary means to analyse the phylogenetic relationships between the three species.

\section{METHODS}

Bacterial strains and culture conditions. The saprophytic/PI strains used in this study were $B$. bacteriovorus strain $100^{\mathrm{T}}$ $\left(=\right.$ ATCC $25622^{\mathrm{T}}$ ), B. stolpii Uki2 ${ }^{\mathrm{T}}$ (= ATCC 27052 ${ }^{\mathrm{T}}$ ), B. starrii A3.12 $2^{\mathrm{T}}$ (= ATCC $\left.15145^{\mathrm{T}}\right)$, B. bacteriovorus $\mathrm{Ox} 9-2$ (= ATCC 25630), B. bacteriovorus E (= ATCC 25634), B. bacteriovorus $2484 \mathrm{Se} 2$ (= ATCC 25635). PI strain $B$. bacteriovorus $109 \mathrm{~J}$ was obtained from $M$. Thomashaw, Michigan State University, East Lansing, MI, USA. All PI strains were maintained on peptone/yeast extract media ( $1 \%$ Bacto-peptone; $0.3 \%$ yeast extract and $1.5 \%$ Bactoagar) at $25^{\circ} \mathrm{C}$ by weekly transfer (Seidler \& Starr, 1969).

Genomic DNA extraction. In preparation for DNA extraction, cells were harvested by centrifugation (3000 g) for $10 \mathrm{~min}$, the pellets were resuspended in a $5 \mathrm{ml}$ total volume of TE buffer (10 mM Tris, $1 \mathrm{mM}$ EDTA, $\mathrm{pH} 8 \cdot 0$ ) containing a final lysozyme (Sigma) concentration of $2 \mathrm{mg} \mathrm{ml}^{-1}$. Samples were incubated at $30^{\circ} \mathrm{C}$ for $30 \mathrm{~min}$. Following the lysozyme step, genomic DNA was extracted using the CTAB procedure (Ausubel et al., 1987). Phase Lock Gel II B Heavy (5 Prime 3 Prime) was incorporated into the phenol:chloroform:isoamyl alcohol extraction to ensure complete separation of the aqueous phase from any contaminating protein. Samples were treated with $1 \mu$ RNase, DNase-free (500 mg ml $\mathrm{m}^{-1}$ ) (Boehringer Mannheim) for $30 \mathrm{~min}$ followed by a second phenol: chloroform: isoamyl alcohol extraction. DNA was precipitated by the addition of 0.6 vol. 2-propanol, the pellet was washed with $70 \%$ ethanol and resuspended in TE. DNA was quantified by absorption spectrophotometry at $A_{260}$ (Beckman Instruments).

Amplification and sequencing of 16S rDNA. The 16S rDNA from $B$. bacteriovorus $100^{\mathrm{T}}$ and $B$. starrii $\mathrm{A} 3.12^{\mathrm{T}}$ was amplified from total chromosomal DNA prepared as described above using PCR. rDNA-targeted oligonucleotide primers specific for eubacterial 16S rRNA genes [forward primer 8-27, 5'-AGAGTTTGATCCTGGCTCAG-3' (modified from FD1) (Weisburg et al., 1991); reverse primer 1492, 5'-GGTTACCTTGTTACGACTT-3' (Reysenbach et al., 1992; Weisburg et al., 1991) were used in the PCR reaction. PCR fragments were gel-purified and sequenced using a Perkin Elmer Dye Terminator Cycle Sequencing Ready Reaction kit with fluorescent terminators and primers used for PCR amplification. Reactions were run on an ABI 373A sequencing instrument (Applied Biosystems). Initial sequences generated by the universal primers were aligned using the PILEUP function of the GCG Wisconsin Package (v.9, Genetics Computer Group); these aligned sequences were then used to construct Bdellovibrio-specific primers. This method was repeated with each new section of sequence until the entire 16S rDNA sequence was completed. Doublestranded sequencing of the Bdellovibrio 16S rRNA gene was done to ensure accuracy of the sequences.

Phylogenetic analysis. Complete Bdellovibrio 16S rDNA sequences were aligned with the PHYDIT program (Chun, 1995) along with other closely related micro-organisms. Alignments were used to identify hypervariable regions 
within the different sequences and these regions were excluded from the phylogenetic analyses, resulting in a total of $1236 \mathrm{nt}$ sites used in the analyses. Evolutionary trees were inferred by using four treeing algorithms, namely, the Fitch-Margoliash (Fitch \& Margoliash, 1967), maximumlikelihood (Felsenstein, 1981; Olsen et al., 1994), maximumparsimony (Kluge \& Farris, 1969) and neighbour-joining (Saitou \& Nei, 1987) methods. Evolutionary distance matrices for the neighbour-joining and Fitch-Margoliash methods were generated by the method of Jukes \& Cantor (1969). The PHYLIP package (Felsenstein, 1993) was used for the neighbour-joining, Fitch-Margoliash and maximumparsimony analyses while the FASTDNAML program (Olsen et al., 1994) was used for the maximum-likelihood method. The final rooted tree was evaluated by bootstrap analyses of the neighbour-joining method based on 1000 resamplings.

Purification of genomic DNA for DNA-DNA hybridization studies. $\mathrm{CsCl}$ density gradients were prepared according to the procedure described by Ausubel (1987). The density gradients were centrifuged in a Beckman angle Ti70 rotor (Beckman Instruments) at 65000 r.p.m. for $16 \mathrm{~h}$ followed by 50000 r.p.m. for $2 \mathrm{~h}$ at $20^{\circ} \mathrm{C}$. Bands were collected and the ethidium bromide was removed from the samples using a saturated 2-propanol/NaCl solution (Maniatis, 1982). Samples were resuspended in TE and quantified by UV spectrophotometry (Beckman Instruments).

Membrane preparation and DNA labelling. DNA hybridization values were determined using a direct binding assay (Johnson, 1988). The DNA samples were heated to $95^{\circ} \mathrm{C}$ and quickly cooled on ice followed by the addition of one volume of $20 \times \mathrm{SSC}$ to each sample. Either $1 \mu \mathrm{g}$ or $500 \mathrm{ng}$ of each sample was vacuum blotted onto Hybond-N + nylon membranes (Amersham Life Sciences). Target DNA was denatured by soaking the membranes in a solution containing $1.5 \mathrm{M} \mathrm{NaCl}$ and $0.5 \mathrm{M} \mathrm{NaOH}$ for $5 \mathrm{~min}$; this was followed by a neutralization step in a solution containing $1.5 \mathrm{M} \mathrm{NaCl}, 0.5 \mathrm{M}$ Tris/ $\mathrm{HCl}(\mathrm{pH} 7 \cdot 2)$ and 0.001 M EDTA for $1 \mathrm{~min}$. Membranes were allowed to air dry and the DNA was fixed by UV cross-linking. A total of $1 \mu \mathrm{g}$ genomic DNA from each Bdellovibrio strain was labelled with $\left[\alpha_{-}^{32} \mathrm{P}\right] \mathrm{dCTP}$ by random priming using Ready-To-Go DNA labelling beads (Pharmacia Biotech). Subsequently, labelled genomic DNA from each strain was purified with a Sephadex G-25 column (Maniatis et al., 1982).

Hybridization. Membranes were prehybridized in a solution containing $6 \times \mathrm{SSC}, 5 \times$ Denhardt's solution, $0.5 \%(\mathrm{w} / \mathrm{v})$ SDS and $50 \mu \mathrm{g}$ denatured salmon sperm DNA ml ${ }^{-1}$ (Sigma) according to the manufacturer's protocol (HYBOND; Amersham). Labelled genomic DNA $\left(2 \times 10^{6}\right.$ c.p.m. $\left.\mathrm{ml}^{-1}\right)$ was added to the prehybridization solution and the membranes were hybridized for $12 \mathrm{~h}$ at $65^{\circ} \mathrm{C}$. Membranes were washed twice each in $2 \times \mathrm{SSC} / 0 \cdot 1 \%(\mathrm{w} / \mathrm{v}) \mathrm{SDS}$ for $15 \mathrm{~min}$ at room temperature. Membranes were exposed to a PhosphoImager screen (Eastman Kodak), the images were digitized with the STORM 840 PhosphoImager (Molecular Dynamics) and hybridization signals of the target dots were analysed quantitatively with the computer software program IMAGEQUANT v.1.0 (Molecular Dynamics). Complete (100\%) hybridization was defined as the intensity observed when the labelled genomic DNA hybridized to itself.

\section{RESULTS AND DISCUSSION}

Previous studies using partial 16S rRNA sequencing, DNA hybridization studies and $\mathrm{G}+\mathrm{C}$ content have resulted in the classification of B. bacteriovorus $100^{\mathrm{T}}$, B. stolpii $\mathrm{Uki}^{\mathrm{T}}$ and $B$. starrii $\mathrm{A} 3.12^{\mathrm{T}}$ as separate species within the same genus. In this study, complete 16S rDNA sequences were analysed from each of these strains to determine their evolutionary relationship. A similarity analysis comparing the $16 \mathrm{~S}$ rDNA sequences from the three taxonomically recognized Bdellovibrio sp. to $16 \mathrm{~S}$ rDNA sequences from other related taxa within the delta division of the Proteobacteria was performed. After a comparison of $1231 \mathrm{nt}$ sites, the level of similarity between different $B$. bacteriovorus strains used in this study $\left(100^{\mathrm{T}}, 109 \mathrm{~J}\right.$ and $\left.\mathrm{E}\right)$ was found to be $>99.5 \%$. These data are supported by analysis of partial 16S rRNA sequences deposited in GenBank by Donze et al. (1991) which shows the level of similarity between additional $B$. bacteriovorus strains (114, Ox9-2, Ox9-3, 6-5-S and 109D) to be $>97 \%$. In contrast, the similarity between B. bacteriovorus $100^{\mathrm{T}}$ and $B$. stolpii Uki2 ${ }^{\mathrm{T}}$ was found to be only $81.7 \%$, whereas the similarity between $B$. starrii $\mathrm{A} 3.12^{\mathrm{T}}$ and $B$. bacteriovorus $100^{\mathrm{T}}$ was $81 \cdot 2 \%$. These similarity values were as low, and in some cases much lower, than the values observed when $B$. bacteriovorus $100^{\mathrm{T}}$ was compared to other organisms that phylogenetically group in the same clade but are considered to be members of separate genera. Examples of similarity levels between $B$. bacteriovorus $100^{\mathrm{T}}$ and other members of the delta division are as follows: $D e$ sulfovibrio desulfuricans, $81 \cdot 3 \% ;$ Myxococcus xanthus, $82.3 \%$; Geobacter metallireducens, $83.8 \%$; Desulfomonile tiedjei, 84.2\%; Desulfuromonas acetoxidans, $83.5 \%$; and Desulfuromusa kysingii, $83.4 \%$. The percentage similarity between the rDNA sequences from B. stolpii $\mathrm{Uki}^{\mathrm{T}}$ and $B$. starrii $\mathrm{A} 3.12^{\mathrm{T}}$ was significantly higher $(90.0 \%)$.

Complete 16S rDNA sequences were obtained for the PI Bdellovibrio strains B. bacteriovorus $100^{\mathrm{T}}$ and $B$. starrii $\mathrm{A} 3 \cdot 12^{\mathrm{T}}$. Comparison of these sequences with the 16S rDNA sequence for B. stolpii Uki2 ${ }^{\mathrm{T}}$ (M34125) already deposited in the GenBank database revealed substantial sequence differences between all three species. $B$. bacteriovorus $100^{\mathrm{T}}$ was shown to have 224 and $230 \mathrm{bp}$ different from $B$. stolpii $\mathrm{Uki}^{\mathrm{T}}$ and $B$. starrii $\mathrm{A} 3.12^{\mathrm{T}}$, respectively. Only 127 differences in the nucleotide sequence were found when $B$. stolpii $\mathrm{Uki}^{\mathrm{T}}$ and B. starrii $\mathrm{A} 3.12^{\mathrm{T}}$ sequences were compared with each other. It is evident from the $16 \mathrm{~S}$ rDNA sequence similarity values that $B$. bacteriovorus $100^{\mathrm{T}}, B$. starrii A3.12 ${ }^{\mathrm{T}}$ and B. stolpii $\mathrm{Uki}^{\mathrm{T}}$ can be distinguished from one another.

The distant relationship between these three Bdellovibrio sp. is also apparent from the rooted evolutionary tree (Fig. 1) based on the Jukes-Cantor distance model and the neighbour-joining methods. B. bacteriovorus $100^{\mathrm{T}}$ clustered more closely with members of the Desulfomonile, Desulfuromonas, Myxococcus, Geobacter and Desulfuromusa genera. B. stolpii Uki2 ${ }^{\mathrm{T}}$ and B. starrii $\mathrm{A} 3.12^{\mathrm{T}}$ clustered together but outside of the B. bacteriovorus $100^{\mathrm{T}}$ clade. The nucleotide sequence data were also examined with three other tree-making 


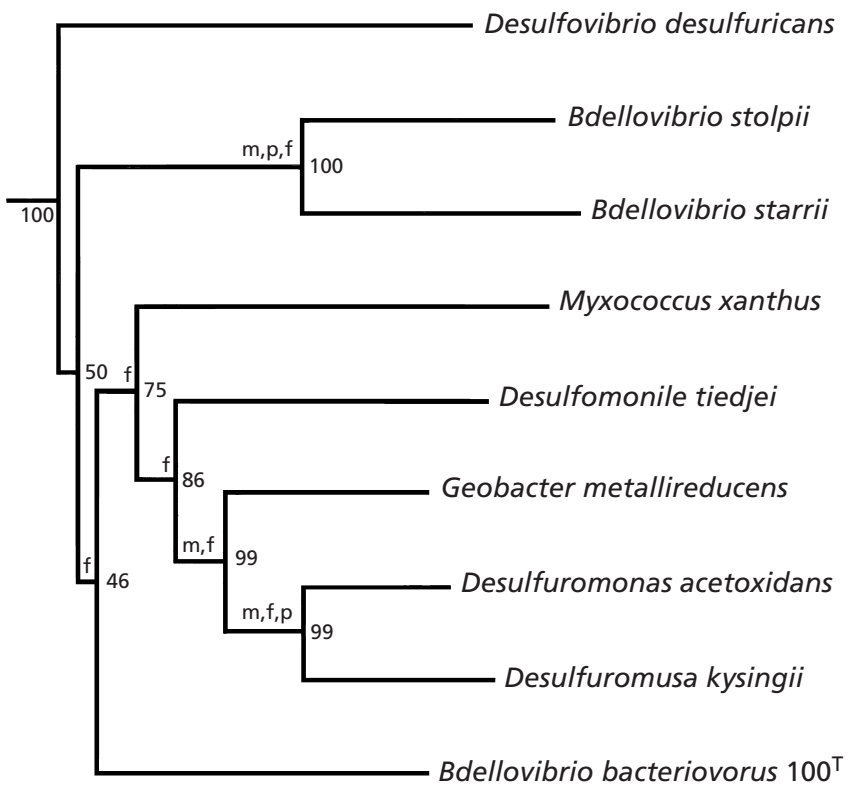

$0 \cdot 1$

Fig. 1. Neighbour-joining tree. Phylogenetic analysis was based on $16 \mathrm{~S}$ rRNA gene sequences (1236 bp) of Bdellovibrio sp. and closely related genera. $m, f$ and $p$ indicate branches that were also found using the FASTDNAML, Fitch-Margoliash and maximum-parsimony algorithms, respectively. The numbers at the nodes represent percentages indicating the level of bootstrap support based on a neighbour-joining analysis of 1000 resampled data sets. The tree was generated using Pasteurella aerogenes $\mathrm{P}-172-71^{\top}$ (M75048) and Xanthomonas phasedi (C. R. Woese, unpublished results) as outgroups. $16 \mathrm{~S}$ rRNA sequences from the following organisms were used to construct the tree (GenBank accession numbers are indicated in parentheses): Desulfomonile tiedjei $\mathrm{DCB}^{\top} \mathrm{1}^{\top} \quad$ (M26635); Geobacter metallireducens GS-15 ${ }^{\top}$ (L07834); Desulfuromonas acetoxidans 11070 (M26634); Desulfuromusa kysingii Kysw2 ${ }^{\top}$ (X79414); Myxococcus xanthus MD207 (M34114); and Desulfovibrio desulfuricans ATCC 27774 (M34113).

algorithms: maximum-parsimony, maximum-likelihood and Fitch-Margoliash methods. All three methods produced similar results to the neighbourjoining algorithm. It is clear from the 16S rDNA sequence data that $B$. bacteriovorus $100^{\mathrm{T}}$ belongs in a separate clade with only a distant relationship to the other two Bdellovibrio species investigated in this study.

Results of the DNA-DNA hybridization study are shown in Table 1. This Table shows the high degree of hybridization (70-100\%) observed between four of the different strains of $B$. bacteriovorus $\left(100^{\mathrm{T}}, 109 \mathrm{~J}\right.$, Ox9-2 and E) tested in this study. A lower degree of hybridization $(32-55 \%)$ was found between $B$. bacteriovorus $2484 \mathrm{Se} 2$ and the other four B. bacteriovorus strains tested. Very low hybridization values were also observed between B. bacteriovorus strains $\left(100^{\mathrm{T}}\right.$ as well as other strains $109 \mathrm{~J}, \mathrm{Ox} 9-2$, E and 2484Se2) and both B. stolpii $\mathrm{Uki}^{\mathrm{T}}(<3 \%)$ and B. starrii $\mathrm{A} 3.12^{\mathrm{T}}(<4 \%)$.
Similar hybridization values were observed between $B$. stolpii $\mathrm{Uki}^{\mathrm{T}}$ and $B$. starrii $\mathrm{A} 3.12^{\mathrm{T}}(4 \%)$. Reciprocal hybridization yielded similar results. Furthermore, these results are consistent with a previous report that demonstrated very little hybridization between $B$. bacteriovorus $100^{\mathrm{T}}$ and the other two species $(1 \%$ hybridization with $B$. starrii $\mathrm{A} 3.12^{\mathrm{T}}$ and no hybridization with B. stolpii Uki2 ${ }^{\mathrm{T}}$ ) (Seidler et al., 1972). Although these investigators observed a slightly higher degree of hybridization ( $16 \%$ ) between B. stolpii $\mathrm{Uki}^{\mathrm{T}}$ and $B$. starrii $\mathrm{A} 3.12^{\mathrm{T}}$ than was observed in the present study $(4.0 \%)$, this was most likely due to the different methods employed.

The present investigation provides further evidence that the genus Bdellovibrio consists of molecularly diverse groups of micro-organisms, which are not closely related to each other. It is clear that use of the predatory lifestyle as the sole criterion for classification of these organisms has resulted in the inclusion of phylogenetically diverse groups within the same genus. Based on the 16S rDNA sequence analysis and the DNA-DNA hybridization results reported in this investigation, it is clear that the two species $B$. stolpii $\mathrm{Uki}^{\mathrm{T}}$ and $B$. starrii $\mathrm{A} 3.12^{\mathrm{T}}$ belong in a separate genus within the evolutionary line that encompasses the delta division of the Proteobacteria. It is proposed, therefore, that B. stolpii $\mathrm{Uki}^{\mathrm{T}}$ and $B$. starrii $\mathrm{A} 3.12^{\mathrm{T}}$ be reclassified into the new genus, Bacteriovorax gen. nov. as Bacteriovorax stolpii comb. nov. and Bacteriovorax starrii comb. nov., respectively.

\section{Nucleotide sequence accession numbers}

The EMBL accession numbers for the 16S rDNA sequences which were determined in this study are as follows: Bdellovibrio bacteriovorus $100^{\mathrm{T}}$, AF084850; and Bacteriovorax starrii, AF084852. The 16S rRNA sequence from Bacteriovorax stolpii was previously deposited in GenBank by C. R. Woese under EMBL accession number M34125. The partial 16S sequences from other $B$. bacteriovorus strains used for comparison purposes in the similarity analysis were deposited previously in GenBank by Donze et al. (1991) under the following EMBL accession numbers: 109D (M61235); 114 (M61230); Ox9-2 (M61232); Ox9-3 (M61233); and 6-5-S (M61237).

\section{Description of Bacteriovorax gen. nov.}

Bacteriovorax (Bac.te.ri.o.vo'rax. Gr. dim. n. baktron small rod; L. n. vorax devourer; bacteriovorax devourer of bacteria).

Members of this genus exhibit a biphasic life cycle, with the potential of displaying an actively predacious form as well as a PI, saprophytic form capable of growing on nutrient medium. Prey-dependent (wildtype) strains are comma-shaped rods, $0.5-1.4 \mu \mathrm{m}$ in length which demonstrate a predatory lifestyle in the presence of susceptible prey bacteria. The wild-type strains are motile by a single, polar flagellum. PI cells (mutants) are pleomorphic, demonstrating a range of 
Table 1. DNA-DNA hybridization values

DNA-DNA hybridization values were determined using a direct binding assay and represent the DNA relatedness (\%) found between different Bdellovibrio strains. Complete $(100 \cdot 0 \%)$ hybridization corresponds to the intensity measured when labelled genomic DNA is hybridized to itself.

\begin{tabular}{|c|c|c|c|c|c|c|c|}
\hline \multirow[t]{2}{*}{ Labelled strain } & \multicolumn{5}{|c|}{ B. bacteriovorus } & \multirow{2}{*}{$\begin{array}{c}\text { B. stolpii } \\
\text { Uki2 }^{\mathrm{T}}\end{array}$} & \multirow{2}{*}{$\begin{array}{c}\text { B. starrii } \\
\text { A3.12 }\end{array}$} \\
\hline & $100^{\mathrm{T}}$ & $109 J$ & Ox9-2 & $\mathbf{E}$ & 2484Se2 & & \\
\hline B. bacteriovorus $100^{\mathrm{T}}$ & $100 \cdot 0$ & $100 \cdot 0$ & $72 \cdot 2$ & $96 \cdot 0$ & $44 \cdot 8$ & $2 \cdot 6$ & $4 \cdot 4$ \\
\hline B. bacteriovorus $109 \mathrm{~J}$ & $100 \cdot 0$ & $100 \cdot 0$ & $88 \cdot 2$ & $91 \cdot 0$ & $32 \cdot 1$ & $3 \cdot 1$ & $2 \cdot 0$ \\
\hline B. bacteriovorus $\mathrm{O} \times 9-2$ & $75 \cdot 0$ & $87 \cdot 5$ & $100 \cdot 0$ & $92 \cdot 1$ & $52 \cdot 6$ & $2 \cdot 1$ & $3 \cdot 7$ \\
\hline B. bacteriovorus $\mathrm{E}$ & $94 \cdot 5$ & $89 \cdot 4$ & $88 \cdot 5$ & $100 \cdot 0$ & $32 \cdot 6$ & $2 \cdot 9$ & 1.9 \\
\hline B. bacteriovorus $2484 \mathrm{Se} 2$ & $41 \cdot 7$ & $35 \cdot 2$ & $54 \cdot 7$ & $36 \cdot 4$ & $100 \cdot 0$ & $0 \cdot 0$ & $2 \cdot 2$ \\
\hline B. stolpii $\mathrm{Uki}^{\mathrm{T}}$ & $2 \cdot 8$ & $2 \cdot 2$ & $2 \cdot 5$ & $2 \cdot 3$ & $0 \cdot 0$ & $100 \cdot 0$ & $4 \cdot 2$ \\
\hline B. starrii $\mathrm{A} 3.12^{\mathrm{T}}$ & $4 \cdot 1$ & $2 \cdot 5$ & $3 \cdot 1$ & $3 \cdot 0$ & $3 \cdot 1$ & $4 \cdot 0$ & $100 \cdot 0$ \\
\hline
\end{tabular}

cell shapes from simple rods to long, tightly spiral shaped cells. The mutants are motile upon initial isolation, but lose their motility after repeated transfer on solid media. Gram-negative. Oxidase- and catalasepositive. Some PI mutants may demonstrate variable catalase activity as some strains have been shown to lose this ability upon repeated transfer. Obligately aerobic. The $\mathrm{G}+\mathrm{C}$ content for members of this genus is $41 \cdot 0-43 \cdot 5 \mathrm{~mol} \%$. This genus demonstrates little to no DNA-DNA hybridization $(<4 \%)$ with the Bdellovibrio genus, although they were previously considered to belong with the bdellovibrios. Comparisons of total genomic restriction digest patterns (PFGE) generated for B. stolpii $\mathrm{Uki}^{\mathrm{T}}$ and B. starrii $\mathrm{A} 3.12^{\mathrm{T}}$ demonstrate little similarity to the patterns produced by members of the Bdellovibrio genus (Baer et al., 1998). Similar results have been observed when comparing arbitrarily primed amplification profiles (AP-PCR) (Baer et al., 1998). rDNA sequence analysis demonstrates that the two species placed within this genus are more closely related to each other $(>90 \%$ rDNA sequence similarity) than to the other members of the delta division of the Proteobacteria (Desulfovibrio, Myxococcus, Bdellovibrio, Desulfomonile, Desulfuromusa, Desulfuromonas and Geobacter). Bacteriovorax stolpii comb. nov. has been designated the type species for this genus.

\section{Description of Bacteriovorax stolpii comb. nov.}

Bacteriovorax stolpii (stol'pi.i. M.L. gen. masc. n. stolpii of Stolp, named after the German microbiologist Heinz Stolp).

The description of Bacteriovorax stolpii comb. nov. below is based on the original description by Seidler et al. (1972) and our own data. Strain Uki2 ${ }^{\mathrm{T}}$ is the only isolate described at this time and is the type strain of Bacteriovorax stolpii comb. nov. This isolate has a $\mathrm{G}+\mathrm{C}$ content of $41.8 \mathrm{~mol} \%$ (Seidler et al., 1972). The optimal temperature range for growth of this organism is $15-35^{\circ} \mathrm{C}$. The major cellular fatty acids are $15: 1 \omega 8 c$,
13:0 and 13:0iso (Guether et al., 1993). Uki2 ${ }^{\mathrm{T}}$ is sensitive to most antibiotics tested (penicillin, streptomycin, neomycin, kanamycin, gentamicin, methicillin, nalidixic acid, pteridine $0 / 129$ and vancomycin) (Guether \& Williams, 1993).

\section{Description of Bacteriovorax starrii comb. nov.}

Bacteriovorax starrii (star'ri.i. M.L. gen. masc. n. starrii of Starr, named after the American microbiologist Mortimer P. Starr).

The description of Bacteriovorax starrii comb. nov. below is based on the original description by Seidler et al. (1972) and our own data. Only one strain, A3.12 ${ }^{\mathrm{T}}$, has been described to date and is the type strain of Bacteriovorax starrii comb. nov. It has a $\mathrm{G}+\mathrm{C}$ ratio of $43.5 \mathrm{~mol} \%$ (Seidler et al., 1972). The major cellular

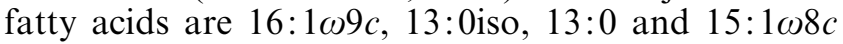
(Guether et al., 1993). A3.12 ${ }^{\mathrm{T}}$ is sensitive to a range of antibiotics (penicillin, streptomycin, neomycin, kanamycin, gentamicin, methicillin and vancomycin) but demonstrates resistance to vibriostat pteridine $0 / 129$ and nalidixic acid (Guether \& Williams, 1993). The optimal temperature range for growth of this organism is $20-30{ }^{\circ} \mathrm{C}$. Phylogenetically, Bacteriovorax starrii comb. nov. is most closely related to Bacteriovorax stolpii comb. nov., as determined by $16 \mathrm{~S}$ rDNA sequence analysis.

\section{ACKNOWLEDGEMENTS}

This material is based upon work supported by the National Science Foundation under grant numbers OCE 9615515 and OCE 9731055. We would like to thank Dr Hans Trüper for his advice and assistance with bacterial nomenclature.

\section{REFERENCES}

Althauser, M., Samsonoff, W. A., Anderson, C. \& Conti, S. F. (1972). Isolation and preliminary characterization of bacteriophages for Bdellovibrio bacteriovorus. J Virol 10, 516-523. 
Ausubel, F. M., Brent, R., Kingston, R. E., Moore, D. D., Smith, J. A., Seidman, J. G. \& Struhl, K. (1987). Current Protocols in Molecular Biology. New York: Greene Publishing Associates and Wiley-Interscience.

Baer, M. L., Ravel, J., Schoeffield, A. J., Hill, R. T. \& Williams, H. N. (1998). Analysis of Bdellovibrio sp. by arbitrarily primed PCR, pulsed field gel electrophoresis, ribotyping and 16S rDNA analysis. Abstract R-13 presented at the 98th General Meeting for the American Society for Microbiology, Atlanta, Georgia, USA.

Burnham, J. C. \& Conti, S. F. (1984). Genus Bdellovibrio. In Bergey's Manual of Systematic Bacteriology, pp. 118-124. Edited by N. R. Krieg \& J. G. Holt. Baltimore: Williams \& Wilkins.

Chun, J. (1995). Computer-assisted classification and identification of actinomycetes. $\mathrm{PhD}$ thesis, University of Newcastle upon Tyne.

Donze, D., Mayo, J. A. \& Diedrich, D. L. (1991). Relationships among the bdellovibrios revealed by partial sequences of $16 \mathrm{~S}$ ribosomal RNA. Curr Microbiol 23, 115-119.

Felsenstein, J. (1981). Evolutionary trees from DNA sequences: a maximum-likelihood approach. J Mol Evol 17, 368-376.

Felsenstein, J. (1993). PHYLIP (Phylogenetic inference package), version 3.5c. Department of Genetics, University of Washington, Seattle, Washington, USA.

Fitch, W. M. \& Margoliash, E. (1967). Construction of phylogenetic trees. Science 155, 279-284.

Guether, D. L. \& Williams, H. N. (1993). Antibiogram characterization of aquatic and terrestrial Bdellovibrio isolates. Abstract Q-244 presented at the 93rd General Meeting of the American Society for Microbiology, Atlanta, Georgia, USA.

Guether, D. L., Osterhout, G. J., Dick, J. D. \& Williams, H. N. (1993). Analysis of fatty acid composition of Bdellovibrio isolates. Abstract Q-243 presented at the 93rd General Meeting of the American Society for Microbiology, Atlanta, Georgia, USA.

Hashimoto, T., Diedrich, D. L. \& Conti, S. F. (1970). Isolation of a bacteriophage for Bdellovibrio bacteriovorus. J Virol 5, 97-98.

Hespell, R. B., Paster, B. J., Macke, T. J. \& Woese, C. R. (1984). The origin and phylogeny of the bdellovibrios. Syst Appl Microbiol 5, 196-203.

Johnson, J. L. (1988). Bacterial classification: nucleic acids in bacterial classification. In Bergey's Manual of Systematic Bacteriology, pp. 2306-2309. Edited by S. T. Williams, M. E. Sharpe \& J. G. Holt. Baltimore: Williams \& Wilkins.

Jukes, T. H. \& Cantor, C. R. (1969). Evolution of protein molecules. In Mammalian Protein Metabolism, vol. 3, pp. 21-132. Edited by H. N. Munro. New York: Academic Press.

Kluge, A. G. \& Farris, F. S. (1969). Quantitative phyletics and the evolution of anurans. Syst Zoo 18, 1-32.
Maniatis, T. E., Fritsch, E. F. \& Sambrook, J. (1982). Molecular Cloning : a Laboratory Manual, 2nd edn. Cold Spring Harbor: Cold Spring Harbor Laboratory.

Olsen, G. J., Matsuda, H., Hagstrom, R. \& Overbeek, R. (1994). FASTDNAML: a tool for construction of phylogenetic trees of DNA sequences using maximum likelihood. Comp Appl Biosci 10, $41-48$.

Oyaizu, H. \& Woese, C. R. (1985). Phylogenetic relationships among the sulfate respiring bacteria, Myxobacteria and Purple Bacteria. Syst Appl Microbiol 6, 257-263.

Reysenbach, A. L., Giver, L. J., Wickham, G. S. \& Pace, N. R. (1992). Differential amplification of rRNA genes by polymerase chain reaction. Appl Environ Microbiol 58, 3417-3418.

Saiki, R. K., Gelfand, D. H., Stoffel, S., Scharf, S. J., Higuchi, R., Horn, G. T., Mullis, K. B. \& Erlich, H. A. (1988). Primer-directed enzymatic amplification of DNA with a thermostable DNA polymerase. Science $\mathbf{2 3 9}$, 487-491.

Saitou, N. \& Nei, M. (1987). The neighbor-joining method: a new method for reconstructing phylogenetic trees. Mol Biol Evol 4, 406-425.

Schelling, J. E., Anderson, C. \& Conti, S. F. (1977). Serotyping of bdellovibrios by agglutination and indirect immunofluorescence. Abstract I-146 presented at the 77th General Meeting of the American Society for Microbiology, New Orleans, Louisiana, USA.

Scognamiglio, T. \& Tudor, J. J. (1996). Macrorestriction patterns and partial genomic map of Bdellovibrio. Abstract $\mathrm{H}-55$ presented at the 96th General Meeting of the American Society for Microbiology, New Orleans, Louisiana, USA.

Seidler, R. J. \& Starr, M. P. (1969). Isolation and characterization of host-independent bdellovibrios. J Bacteriol 100, 769-785.

Seidler, R. J., Mandel, M. \& Baptist, J. N. (1972). Molecular heterogeneity of the bdellovibrios: evidence for two new species. J Bacteriol 109, 209-217.

Stackebrandt, E. (1988). Phylogenetic relationships vs phenotypic diversity: how to achieve a phylogenetic classification system of the eubacteria. Can J Microbiol 34, 552-556.

Starr, M. P. \& Baigent, N. L. (1966). Parasitic interaction of Bdellovibrio bacteriovorus with other bacteria. J Bacteriol 91, 2006-2017.

Varon, M. \& Levisohn, R. (1972). Three-membered parasitic system: a bacteriophage, Bdellovibrio bacteriovorus, and Escherichia coli. J Virol 9, 519-525.

Weisburg, W. G., Barns, S. M., Pelletier, D. A. \& Lane, D. J. (1991). $16 \mathrm{~S}$ ribosomal DNA amplification for phylogenetic study. $J$ Bacteriol 173, 697-703.

Woese, C. R. (1987). Bacterial evolution. Microbiol Rev 51, 221-271. 